\title{
THE EFFECTIVENESS OF SKILL TRAINING MODEL FOR INCREASING THE STREET CHILDREN'S COMPETENCE TO GET A JOB
}

\author{
Murhadi \\ Sekolah Tinggi Pariwisata Sahid \\ J1. Jend Sudirman Kav. 86 Karet Tengsin Tanah Abang Jakarta 10220, Indonesia \\ murhadi@stpsahid.ac.id
}

\begin{abstract}
This research was based on the importance of the effectiveness of skills training for street children as a solution to reduce their activity of begging money on the street. Referring to the problem, there were two objectives in this study. First, it was to obtain an overview of the skill training conditions undertaken by street children in Depok as the multi-location test and Tangerang Selatan as the main research location. Second, it was to know the effectiveness of the implementation of skills training in improving the competence of street children to get a job. Several theories and concepts were used as the reference in the implementation of this study. The method was Research and Development $(R \& D)$ and quasi-experimental approach. Data were collected through participant observation, documentation, interview, questionnaire, and group discussion. The results of this research show that effective training can provide skills for street children to get a job.
\end{abstract}

Keyword: training effectiveness, street children skill, street children competence

\section{INTRODUCTION}

The development of street children in Depok becomes a problem. However, it can be solved by government, community, and company. Corporate Social Responsibility (CSR) programs from companies are not only in the form of funding support but also skills training and employment of street children. The street children should be given the training that has the skills and competence in accordance with the requirements of the company. Living as street children is not a favorable option for anyone. It is the uncomfortable environment and the risks like violence. However, their existence is common for many people, families, communities, and countries (Barton, 1998; Wibowo, 2017). Children who spend most of their times on the street tend to lose their time to study and to socialize. It causes them to terminate their study. Nevertheless, they have to sing on the street or beg to get money. The attention to the street children is not good, and there is no appropriate solution to address this problem. According to Putra, Hasanah, and Nuriyah (2016), street children are a reality as the part of the urban city. People define street children by the type of work that they do. They are often referred to singers, scavengers, hawkers, beggars, newspaper sellers, umbrella-makers, shoe polishers, parking attendants, car cleaners, jockeys, and others.

In this study, the researcher chooses Depok where the street children are guided by the street children manager at Sekolah Master. It is a place to recruit street children and poor children, so they can receive coaching, education, and training to achieve a bright future. Coaching that has been done concerns with religion related to morals, behavior, and confidence. Moreover, education is for elementary, junior, and senior high schools. Meanwhile, skills training taught is for work. Coaching, education, and training activities for street children are supported by volunteers such as teachers, trainers from campuses, communities, and donors. Many alumni have graduated from the school, and 
some of them partially help in fostering street children. According to Aziz (2016), the street children do not know and do not want to know the benefits of the knowledge provided. Nurindah, Afiatin, and Sulistyarini (2012) have suggested after several trainings; the participants start to be active. They express their opinions, more cooperative, and share their experiences and feelings during the trainings. In the implementation of this program, there are many problems such as funding, equipment, and various characters of street children that need special attention. The supports from government, donors, community, and volunteers are needed for this activity to run smoothly.

This study has several objectives. The first is to find out the description of training conducted by social community and street children manager in Sekolah Master in handling encountered problems. The second is to know how effective the training activity toward its outcome. The third is to know the evaluation of the activities that have been done both by the social community and street children manager of Sekolah Master.

Nitisemito (2010), Steiner et al. (2014), and Zima, Wells, and Freeman (1994) have revealed the purpose of training as an effort to improve and develop attitudes, behaviors, and knowledge. It is in accordance with the need of concerned individuals and institutions. Thus, training is intended in a broader sense that is not limited solely to develop skills and guidance. On the other hand, Nadler and Tushman (1988) have emphasized that training is an urgent individual development lesson because of the current needs. The view is derived from the assumption that the fulfillment of individual to achieve satisfaction require the knowledge and skills of the individual either by starting or developing particular activity.

\section{METHODS}

This research uses the problem-solving method based on trial error approach and concept testing stage, concept application, evaluation, and target. This research describes the case study about the effectiveness of skills training in increasing the competence of street children to get a job. It is as one of the government's solutions in minimizing the level of crime against street children. This research is done by using previous research methods and qualitative approach. From ten stages of previous research, this research uses four steps. Those are preliminary study by covering literature study and limited survey, development of a conceptual model, model implementation (field test), and recommendation of final mode. Data collection is conducted through in-depth interviews with social community, street children managers, and businessman in that area. In addition, seminars or discussion forums are held to provide input to the skills training that will be implemented. Thus, this model becomes the input material in the training activities.

For successful and effective training, the used training method and instruction should be appropriate to the type of training. Although there is no perfect method, several alternative methods can be used to fit the characteristics of the trainees. One of the methods is the model developed by Nadler and Tushman (1988). The model consists of determining the needs of the organization, determining the specific task implementation, determining the learning needs, formulating the goals, determining the curriculum, obtaining learning resources, and conducting the training that has been implemented to see whether it still needs to be improved or in accordance with the goals desired by the organization.

The government, social community, street children manager, and company should be involved in the effective training model. Social community and street children managers must work with communities, entrepreneurs, and company in implementing the training. Then, they should evaluate 
the effectiveness of the training that has been implemented by the government then comparing it with the training model that will be implemented.

\section{RESULT AND DISCUSSIONS}

The research location is in Depok as the multi-location test and Tangerang Selatan as the main location. There are basic consideration and an academic reason why the researcher selects Depok to analyze the effectiveness of skills training model in increasing the competence for street children to get a job. The street children manager has trained and educated for street children. It is managed by Sekolah Master. The street children manager in Sekolah Master provides training to street children periodically. The purpose of the training is that the street children possess the skills and competencies so that they can get a job. The street children manager assists the training activities, and street children gather to follow the training and formal education. Many of the alumni have succeeded the program and continue to college. Moreover, it is expected that the street children do not return to the street for working or begging. The basic principle of training is interpreted as the systematic and deliberated effort by educators to create the conditions for learners to learn (Sudjana, 2004). In this activity, there is an educational interaction between two parties; participants who learn and educators who teach.

There are three elements in this study. First, street children manager and Sekolah Master are the media to organize training as well as a place to educate and foster street children. Second, street children are the main object as in this study. Third, donors or companies are the funders of the development and training for street children. The profile of the street children can be seen in Table 1 .

Table 1 Gender of Street Children

\begin{tabular}{ccc}
\hline Gender & Amount & Percentage \\
\hline Male & 24 & $80 \%$ \\
Female & 6 & $20 \%$ \\
\hline Total & 30 & $100 \%$ \\
\hline \multicolumn{2}{r}{ (Source: Researcher, 2017) }
\end{tabular}

Table 2 shows that street children in the Depok consist of mainly male with the $80 \%$ of the 30 populations. From the survey results, it can be seen that male street children have the freedom and strong courage to live on the street. They gather with their friends for begging, singing, and spending time on the street. The average age of street children is between $15-18$ years that is about $33 \%$. From the survey results, it is the age which street children require identity. In this case, effective coaching and training can be a solution in overcoming street children problem.

Table 2 Age of Street Children

\begin{tabular}{|c|c|c|c|}
\hline \multirow[t]{2}{*}{ Age } & \multicolumn{2}{|c|}{ Amount } & \multirow[t]{2}{*}{ Percentage } \\
\hline & Male & Female & \\
\hline $7-10$ years & 5 & 3 & $27 \%$ \\
\hline $11-14$ years & 5 & 3 & $27 \%$ \\
\hline $15-18$ years & 14 & 0 & $33 \%$ \\
\hline Total & 24 & 6 & $100 \%$ \\
\hline
\end{tabular}


In Table 3, the education of street children is mainly high school that is $33 \%$. The children need big fund in education cost. It causes the street children to help fulfill the requirement of school by begging or working. Thus, the solution to overcome the problems of street children concerns use skill provisions in working, so they do not work on the streets.

Table 3 Education of Street Children

\begin{tabular}{lccc}
\hline \multirow{2}{*}{ Education } & \multicolumn{2}{c}{ Amount } & Percentage \\
\cline { 2 - 3 } & Male & Female & \\
\hline Primary School & 5 & 3 & $27 \%$ \\
Junior high school & 5 & 3 & $27 \%$ \\
Senior High School & 10 & 0 & $33 \%$ \\
No School & 4 & 0 & $13 \%$ \\
\hline \multicolumn{1}{c}{ Total } & 24 & 6 & $100 \%$ \\
\hline \multicolumn{4}{c}{}
\end{tabular}

The number of street children in Depok increases that are not significantly in line with the number and those of street children who apply in School Master. Several factors can cause the number of street children to increase. First, it is economic factors. In the financial situation, their parents cannot fulfill daily meals, school fees, and other living expenses. Second, the children are influenced by others. From the results of interviews, the street children are invited or influenced by their friends who do not go to school because of dropping out case. It is also because of their playmates in daily activities so that they become street children and try to make money instead of studying. This friendship factor causes the number of street children to increase. Third, it can be violence at home. The emergence of street children may be caused by parents' violence in educating their children. Thus, they do not feel comfortable because of the pressures from the parents. Fourth, it is parental divorce. The children take the initiative to make money on the streets to help the economy of their family. Fifth, the children cannot overcome the sense of inferior because of social status, the environment, or their friends. Sixth, the children are kidnapped or forced by certain people. Thus, they are exploited to work as the street children. Moreover, the reason why the street children can survive is their view of the unclear future. They do not know or are still confused when they are asked about their dream. Mostly the street children respond like other children, but they do not know how to reach that dream.

The training to street children in Depok is done by the street children manager in Sekolah Master continuously. It wants to change the mindset of street children to make them optimistic. The training materials are religion, moral, and behavior. The purpose of teaching about religion is to provide the influence and confidence to street children by changing their morale and behavior. In addition, street children are taught English, general knowledge, and formal education material for elementary, junior, and senior high school.

The volunteers for this program are students, teachers, lecturers, trainers, and donors from the community or training and education program that have to prepare the appropriate material. According to Papu (2016), the material on training is very important for volunteers in accompanying street children. This is because the children who live on the streets come from many troubled families. To provide convenience, security, and sustainability in the process of training the street children, facilities, equipment and financial support from donors, community, and the government are needed.

Based on the study, the researcher can give several overviews. First, the program of training and education for street children are carried out professionally and continuously by the street children manager. It is to foster self-confidence and motivation in street children to live better. Second, the training can reduce the growth rate of street children. Third, for the implementation of the training to 
run smoothly, the support of funding and operational equipment in this activity by governments, communities, and donors are required.

There are several stages for more effective training activities. First, in choosing the training, it must in line with the need of street children or the demand of company. Second, the output of training provides a direct view of skills as the working skill. Third, training materials should adopt the competencies (knowledge, skills, and attitude) needed by the company. Fourth, training is provided directly by trainers from the company through the simulation and practice methods in accordance with the skills and competencies required.

According to Moekijat (2008), training is a part of education concerning learning process to obtain and improve skills. It is the educational system applied in a relatively short time and with methods preferred for the practice rather than the theory. In this research, the methods are undertaken in the skills training to improve the competence. It involves company and the street children manager as the organizer. The training can be done by trainers or workers in the company so that the skills achieved by participants are the competencies required by the company. In this case, the company can provide CSR program through training. Then, the outcome of the training provides solutions to the problems of street children.

In this research, the street children manager teaches mobile phone maintenance skills. This is taken as the case study to examine the effectiveness of skill training model. This activity is done through the cooperation of street children and trainers from the company. The training is chosen because the development of mobile phones is very fast and is needed by all people. Thus, the maintenance service is needed. The outcome of this training is that the participants can work on mobile phone store. The training is carried out by selecting learning material of mobile phone maintenance for software and hardware. Moreover, the length of time of the training is adjusted to the basic competencies that the technician must have in fixing the phone. Then, the participants are guided by the experienced trainers in the maintenance of mobile phone.

According to Sari and Sumarti (2017), to measure the effectiveness of a program, it can be done by using the several variables. First, it is the accuracy of program targets. It is how far the participants fit the target that has been predetermined. Second, it is socialization of the program. It is the ability of the organizers in planning the program so that information can be delivered to the public in general and the target participants in particular. Third, it is the achievement of the program. It is how the results of the program implementation match with the objectives of the program. Fourth, monitoring of program is the activities after the implementation of the program.

To find out the effectiveness of street children training in accordance with the planned program and objectives, it is necessary for the street children manager to evaluate the results of street children training. The program evaluation is a good determination whether it has met the objectives or not. This process consists of; (1) determining the criteria of the good and bad program, (2) finding evidence related to the criteria, and (3) comparing evidence and criteria. In short, the determination of the value or whether it is a well-designed program by comparing the existing evidence with established criteria or prescribed standards.

Based on the comparison between the evidence collected with the research instrument, it can determine the quality of training implemented (good, enough, and bad). The training program is said to be successful or failed from the implementation. It can be seen from several factors. First, from the activity of the participant, they are motivated to be active and have the skills of mobile phone maintenance. The participants have enough spirit and have basic skills in repairing the mobile phone. Second, it can be seen from the skills before and after training. Effective training provides quick and precise results. The participants quickly have skills from training, so they have the asset in working. Last, it is the cooperation of street children manager with the company in implementing the training. It 
is expected that the company gives opportunities for the street children to work. From the results of monitoring, the street children have improved their competence and done the internships at the mobile phone store.

\section{CONCLUSIONS}

The street children manager in Sekolah Master has conducted periodical skill training to street children. The purpose of the activity is that street children have the competence to get a job. Various training has been given to street children to solve social problems. It is expected that the street children have activities that can change then to be better. In the implementation of the training, it has several limitations in the facilities, equipment, and funding support. To increase the effectiveness of skill training, the street children manager collaborate with the community, donors, and company. In addition to providing CSR program, the employee in the company can be a trainer.

From the results, 30 participants attend the training on mobile phone maintenance skill. The participants are expected to have the skills to get a job. Moreover, to improve the effectiveness of the training, the street children manager conducts an evaluation of the training by covering the accuracy of training materials, methods of training, and outcome of the training. The results show that the participants have skills in accordance with certain competencies and they can do an internship in the company.

\section{REFERENCES}

Aziz, E. (2016). Efektifitas program peningkatan keterampilan dan kewirausahaan anak jalanan di kota Palembang. Jurnal Administrasi Publik, 17(2), 38-47.

Barton, A. C. (1998). Teaching science with homeless children: Pedagogy, representation, and identity. Journal of Research in Science Teaching, 35(4), 379-394.

Moekijat. (2008). Manajemen personalia dan sumber daya manusia. Yogyakarta: BFFE.

Nadler, D., \& Tushman, M. (1988). Strategic organization design: Concepts, tools \& processes. New York: Harper Collins.

Nitisemito, A. S. (2010). Manajemen personalia manajemen sumber daya manusia ( $3^{\text {rd }}$ Ed.). Jakarta: Ghalia Indonesia.

Nurindah, M., Afiatin, T., \& Sulistyarini, I. (2012). Meningkatkan optimisme remaja panti sosial dengan pelatihan berpikir positif. JIP: Jurnal Intervensi Psikologi, 4(1), 57-76.

Papu, Y. M. (2016). Pelatihan coach and counseling untuk para pendamping anak jalanan di Yayasan Sahabat Anak melalui strategi WDEP. Psiko-Edukasi, 14(2), 143-151.

Putra, F., Hasanah, D., \& Nuriyah, E. (2016). Pemberdayaan anak jalanan di rumah singgah. SHARE: Social Work Journal, 5(1), 51-64. 
Sari, D. P., \& Sumarti, T. (2017). Analisis efektivitas program pemberdayaan anak jalanan di rumah singgah Tabayun kecamatan Cibinong, Kabupaten Bogor. Jurnal Sains Komunikasi dan Pengembangan Masyarakat [JSKPM], 1(1), 29-42.

Steiner, N. J., Frenette, E. C., Rene, K. M., Brennan, R. T., \& Perrin, E. C. (2014). Neurofeedback and cognitive attention training for children with attention-deficit hyperactivity disorder in schools. Journal of Developmental \& Behavioral Pediatrics, 35(1), 18-27.

Sudjana, D. (2004). Manajemen program pendidikan (Untuk pendidikan non formal dan pengembangan sumber daya manusia). Bandung: Falah Production.

Wibowo, K. P. (2017). Efektivitas pelatihan penerimaan diri pada anak jalanan. Jurnal Ilmiah Psikologi, 8(2), 139-145.

Zima, B. T., Wells, K. B., \& Freeman, H. E. (1994). Emotional and behavioral problems and severe academic delays among sheltered homeless children in Los Angeles County. American Journal of Public Health, 84(2), 260-264. 